\title{
[r]Existo! \\ Coletivo Madeirista
}

\section{I [r] Exist! Madeirista Collective}

\section{¡Yo [r]existo! Colectivo Madeirista}

Coletivo Madeirista (Artistas independentes, Brasil)*

https://doi.org/10.22409/poiesis.v22i37.47268

\begin{abstract}
RESUMO: [r]Existo! é fruto de um trabalho fotográfico do Coletivo Madeirista durante a enchente do Rio Madeira em 2014, a maior de todas nos cem últimos anos, no qual são registrados o avanço das águas e depois a retomada, por parte da população, de suas próprias casas. No ano de 2015, as imagens da cheia retornaram, não com a mesma intensidade, mas trazendo a mesma problemática. Daí a importância desse [r]Existo! O Coletivo Madeirista, grupo de artistas e pensadores que se reúne desde 2001 para produzir e discutir arte contemporânea, literatura e poesia, está sediado em Porto Velho. Suas publicações, net.art, poesia visual, performances, intervenções urbanas e videoarte refletem sobre o estatuto da arte na sociedade contemporânea.
\end{abstract}

PALAVRAS-CHAVE: [r]existência; Rio Madeira; Rondônia; Cheia 2014; ribeirinhos

* O Coletivo Madeirista, sediado em Porto Velho, Rondônia, é formado por Elisabete Christofoletti, Ariana Boaventura, Joezer Alvarez, Nilson Santos, Flavio Dutra, Joezer Júnior e Anderson Silva. E-mail: coletivomadeir@gmail.com. 
ABSTRACT: [r]Existo! is the result from a photography work of Madeirist Collective, during the largest flooding of the last hundred years in 2014 at Madeira River, in which have been recorded the advance of the waters followed by the populations resumptions to their own homes. In 2015, we watched the flood return not with the same intensity but emerging similar issues, and that's the reason why [r]Existo! is so important. Based in Porto Velho, The Coletivo Madeirista/ Madeirista Collective, is a group of artists and thinkers that since 2001 have been together to produce and discuss contemporary art, literature and poetry. Their publications, net.art, visual poetry, performances, urban interventions and video art reflects about the status of art in contemporary society.

KEYWORDS: [r]existence; Madeira River; Rondonia; Flood 2014; riparians

RESUMEN: [r]Existo! es el resultado de un trabajo fotográfico del Colectivo Madeirista durante la inundación del río Madeira en 2014, la mayor de los últimos cien años. Durante ese tiempo, se ha registrado el avanzo de las aguas y un posterior retorno de la población a sus casas. En 2015, las imágenes de la inundación volvieron, no con la misma intensidad, pero trayendo el mismo problema. Por eso se faz la importancia de este [r]Existo! El Colectivo Madeirista, un grupo de artistas y pensadores que se reúne desde 2001 para producir y discutir el arte contemporáneo, la literatura y la poesía, tiene su sede en Porto Velho. Sus publicaciones, net.art, poesía visual, performances, intervenciones urbanas y video arte reflejan el estatus del arte en la sociedad contemporánea.

PALABRAS-CLAVE: [r] existencia; río Madeira; Rondonia; inundácion 2014, ribereño

Citação recomendada:

COLETIVO MADEIRISTA. [r]Existo! Revista Poiésis, Niterói, v. 22, n. 37, p. 165-176, jan./jun. 2021. [https://doi.org/10.22409/poiesis.v22i37.47268]

(cc) BY-NC-ND Este documento é distribuído nos termos da licença Creative Commons Atribuição-NãoComercial 4.0 Internacional (CC-BY-NC) @ 2021 Coletivo Madeirista 


\section{[r]Existo! \\ Coletivo Madeirista}

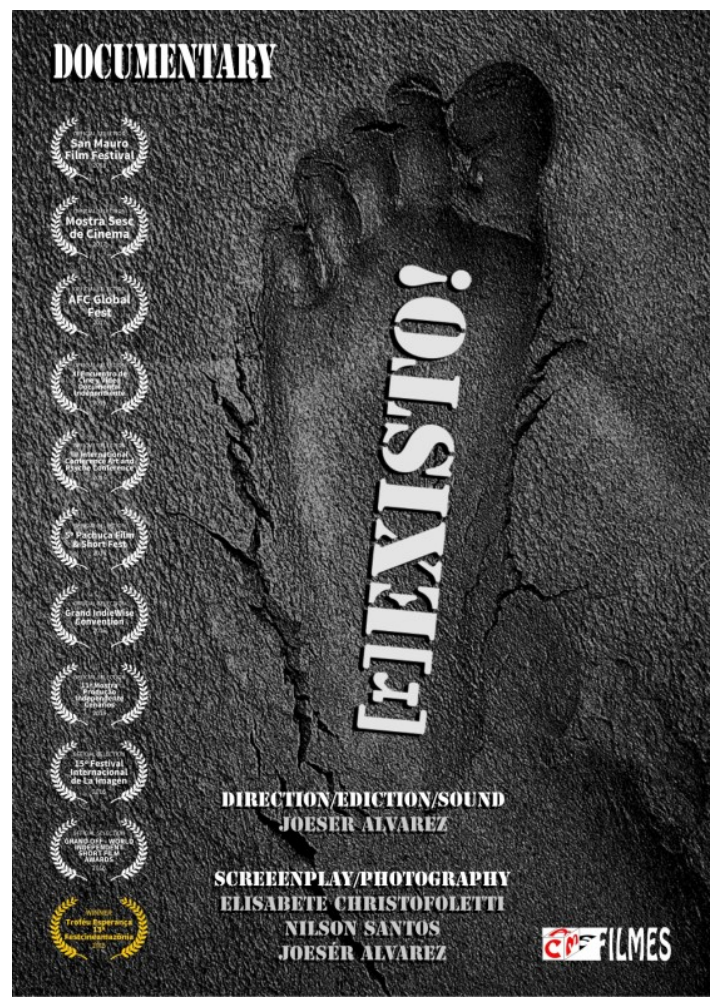

Fig. 1 - Cartaz do Filme [r]Existo!1 2014.

(Fonte: Coletivo Madeirista) 
[r]Existo! é fruto de um trabalho fotográfico durante a enchente do Rio Madeira em 2014, a maior de todas nos cem últimos anos. Registramos o avanço das águas e depois a retomada, por parte da população, de suas próprias casas. Vimos o rio avançar lentamente e com a mesma lentidão retornar ao seu curso normal, sentimos o silêncio das pessoas, os lugares vazios de gente e cheios de água, lama - e o lixo nosso de cada dia.

Ouvimos as famílias desabrigadas falando de suas perdas com uma sabedoria muito peculiar, mas com os olhos atentos e esperançosos quanto ao socorro que deveria ser prestado pelo poder público. Neste processo, estabeleceu-se uma reflexão sobre a relação com o rio, com as casas, a água, a capacidade de re-início, não de RESISTÊNCIA, mas de RE-EXISTÊNCIA, de retorno às mesmas moradias destruídas que formavam uma cena desoladora.

Neste ano de 2015, as imagens da cheia retornaram, não com a mesma intensidade, mas trazendo a mesma problemática, atingindo novamente quase as mesmas pessoas, propondo desafios e soluções ainda não atendidas pelo poder público. Daí a importância desse [r]Existo!

\section{Fotografias, Concepção e Produção:}

Elisabete Christofoletti, Nilson Santos e Joezer Alvarez

Coletivo Madeirista

\section{[r]Existo!}

Quando os nazistas levaram os comunistas, eu calei-me, porque, afinal, eu não era comunista.

Quando eles prenderam os sociaisdemocratas,

eu calei-me, porque, afinal, eu não era socialdemocrata.

Quando eles levaram os sindicalistas, eu não protestei, porque, afinal, eu não era sindicalista.

Quando levaram os judeus, eu não protestei, porque, afinal, eu não era judeu.

Quando eles me levaram, não havia mais quem protestasse. "E NÃO SOBROU NINGUÉM"

--- Martin Niemöller 
Vivemos em tempos de silêncio e de movimentos funcionando no esquema de "boiada". Na falta de consciência, de compreensão, de mudanças de valores e a cada dia uma valorização menor da condição do SER-Humano, da pessoa. Por isso, nos sentimos provocados a sair do silêncio. Sair do silêncio, ou dar voz a ele, é o propósito deste documentário. Buscamos compreender o silêncio e a passividade, a aceitação de um viver sempre muito transitório. Nos lembramos de um dos mitos de origem que compõem o DNA psíquico, a Alma de Porto Velho-RO, e com isso, a atitude, o movimento e a relação com o lugar de quem aqui reside.

"Não importa que a tenham destruído, nós sempre retornamos para a casa onde nascemos". A lembrança não é clara se o verso do poema é exatamente assim e nem mesmo se é de Carlos Drummond de Andrade, mas foi numa viagem que fazíamos pela primeira vez à terra de onde nossos avós vieram que lemos isso numa revista de bordo. Essa fala sempre nos soou muito familiar, não por uma história pessoal, embora a sincronicidade tenha sido grande, mas por identificarmos o verso com a cidade de Porto Velho, local onde as imagens e o documentário foram produzidos.

Localizada na Amazônia, Porto Velho, segundo os historiadores populares, nasceu como um local de trânsito, transição. No trajeto das embarcações pelo leito do rio Madeira (um dos dez maiores rios do mundo), teria existido a casa de um ancião, o velho Pimentel, onde estas mesmas embarcações paravam para viabilizar algumas necessidades e, com o tempo, ali eram deixados pertences, encomendas e recados. A casa do velho, aos poucos, teria se tornado um ponto de encontro e referência. Em seu entorno, outras moradias foram sendo agregadas. Crianças teriam nascido por ali e rapidamente o local tornou-se Porto - Porto do Velho.

A história é longa. Poderíamos abordar aqui várias situações de transitoriedade e de usurpação inclusive na história recente. Usurpar, estar de maneira transitória, parece ser um lugar comum em Rondônia: modus operandi de agredir a terra e quem nela vive. Lembremos a mais recente usurpação, a construção da Usina Hidroelétrica de Santo Antônio, na cachoeira de mesmo nome, marco fundador da região. 
A usina está instalada a três quilômetros do centro da cidade, tornando-se a usina de força hidroelétrica mais próxima de uma cidade em todo o planeta.

Antes da usina em Rondônia, durante muitos anos se utilizou a produção de energia mista hidroelétrica e termoelétrica a um custo bastante alto em relação aos outros Estados. Com a construção da UHE de Santo Antônio, a promessa de consumir energia mais barata não se concretizou, e, após seu funcionamento a partir de 2012, toda a geração de energia resultante foi direcionada para o sudeste, e, mais uma vez, a população foi usurpada. É o velho modus operandi extrativista: o alienígena chega na região, ganha a confiança da população no grito, ou, no papel assinado-assassinato, e vai-se embora, deixando para trás o lixo do luxo. Achamos importante evocar o mito de origem do velho porto, pois esse nos parece significativo na vivência da enchente no ano de 2014. Provavelmente foram vários os fatores que a geraram, e, apesar das advertências e protestos dos ativistas e cientistas de forma contra-hegemônica nos anos de militância que antecederam o fenômeno, assistimos a uma tragédia anunciada.
Na ocasião, à medida em que as águas subiam, os pertences pessoais da população ribeirinha (enquanto havia transporte proporcionado pela prefeitura) eram retirados, mas muita coisa ficou para trás, por incompetência do poder público. O silêncio das famílias que já haviam vivido outros períodos de cheia foi secundado pela falta de credibilidade na eficiência do poder púbico em retirar aquela população de forma a garantir um espaço digno para que a vida pudesse seguir, ainda que em suspensão, e mesmo com o retorno posterior, com a promessa de auxílio para reconstruir o que se perdeu.

No silêncio, faltou diálogo. Diálogo para que, juntos, população e poder público pudessem realocar os trabalhadores do maior centro de comércio popular, chamado de shopping popular, perdendo assim sua condição de trabalho e sustento das famílias. Na expectativa dessa construção conjunta de caminhos de resolução, a resposta foi o silêncio! O silêncio da vida improvisada nas escolas, no incômodo das famílias e diretores que tiveram o início do ano escolar adiado e, com isso, o incômodo conjunto e a desconfiança mútua no uso dos espaços que se tornaram comuns em função das circunstâncias, no 
silêncio de um viver transitório. Sabe-se que as regiões ribeirinhas na Amazônia são propensas a inundações cíclicas, cujas populações atingidas comumente contam com o apoio do governo nessas situações emergenciais. No entanto, alguns órgãos públicos que tinham suas sedes nesses locais nos arredores de Porto Velho, abandonaram essas sedes e quedaram em silêncio, calando diante da própria responsabilidade.

No silêncio da população da cidade que não sofreu diretamente com as cheias, mas ignorou o alagamento, ou mesmo participou do turismo da desgraça, navegando de voadeira pelas áreas alagadas para conferir o desespero ou a ruína das famílias que ali moravam, teria se revelado o caráter da autointitulada "Capital do Agronegócio"? Com a vazante, o silêncio começou ser quebrado, sendo rompido pelas pegadas sem nome e sem identidade, que foram ficando grafadas no sedimento trazido pelas águas, as quais haviam deglutido as casas, objetos e mesmo o centro histórico da Estrada de Ferro Madeira-Mamoré, chão no qual silenciosamente as pessoas foram pisando, construindo pegadas, reafirmando que continuavam vivas, que retornavam ao seu lugar de moradia, de trabalho, de origem.
No dizer silencioso daquelas pegadas, dos objetos abandonados, sem condições de uso, abandonados à própria sorte, a história pessoal e social virara lixo: cenário para a produção de Selfs turísticos. Que maneira é esta de "lidar" com a morte que nos leva a refletir sobre a possibilidade da negação das condições em que se vive, do lugar e mesmo da relação com o ambiente? Seria a não aceitação e incorporação da morte de um homem velho, de lugares por onde se esteve (mesmo que nunca se tenha desejado sair) que colabora para que a memória deixe ser conquistada, levada e refeita pelo novo? Esse tipo de condição pelas que passam migrantes e moradores de regiões de fronteiras seriam aceitáveis? Agredimos a terra onde estamos ou recusamos o relacionamento com essa numa tentativa de não ratificar sua existência enquanto "lugar" gerador de vida? Esse olhar alienígena da ocidentalidade turística pode ser naturalizado impunemente? Negamos o lugar e as pessoas porque negamos a nós mesmos?

\section{Notas}

1 Disponível em https://www.youtube.com/watch ?v=vAJxZpnpnmE. Acesso em 4/10/2020. 


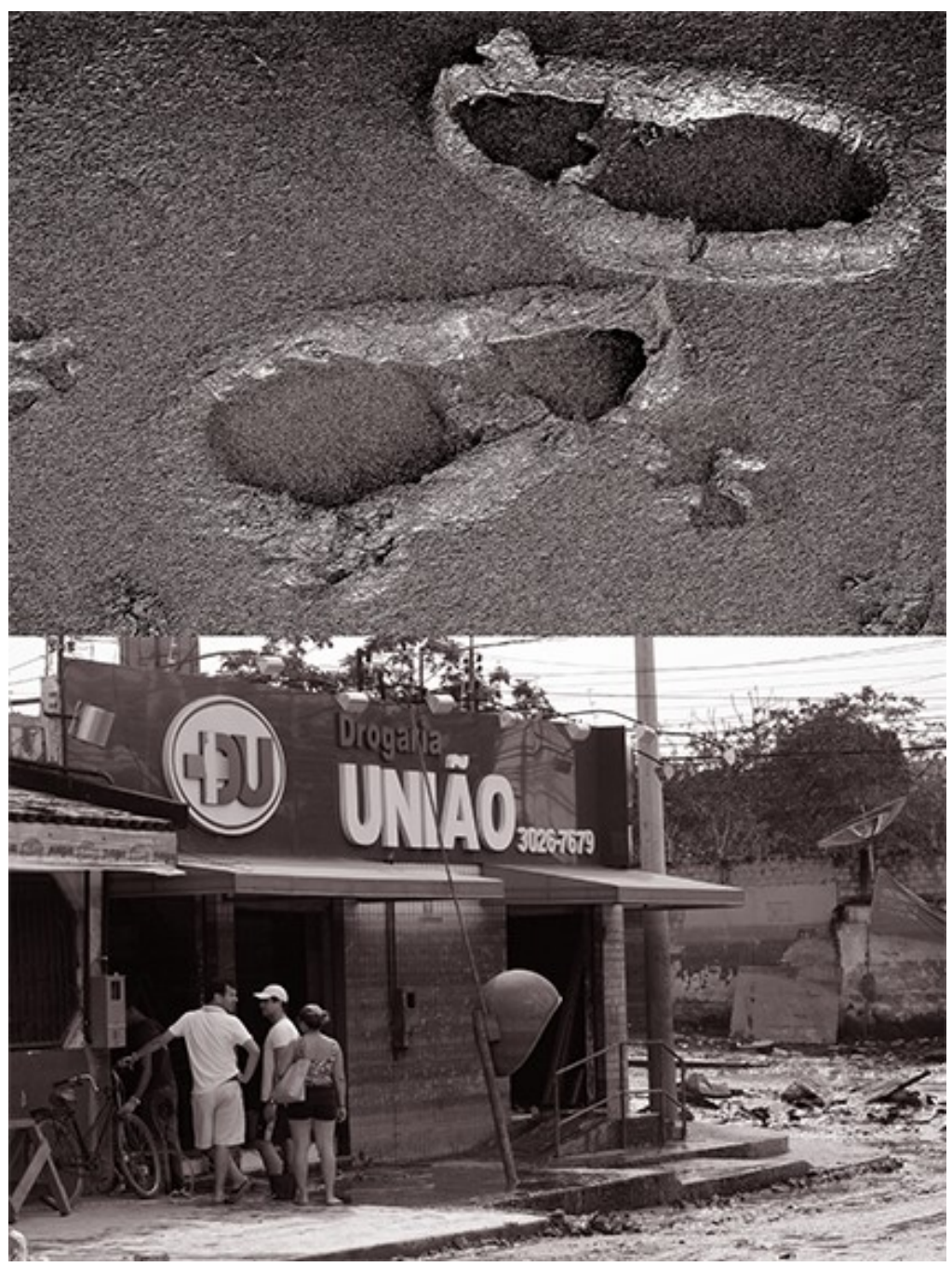

Nesta página e nas subsequentes - Coletivo Madeirista, frames do documentário [r]Existo!, 2014. (Fonte: Coletivo Madeirista) 


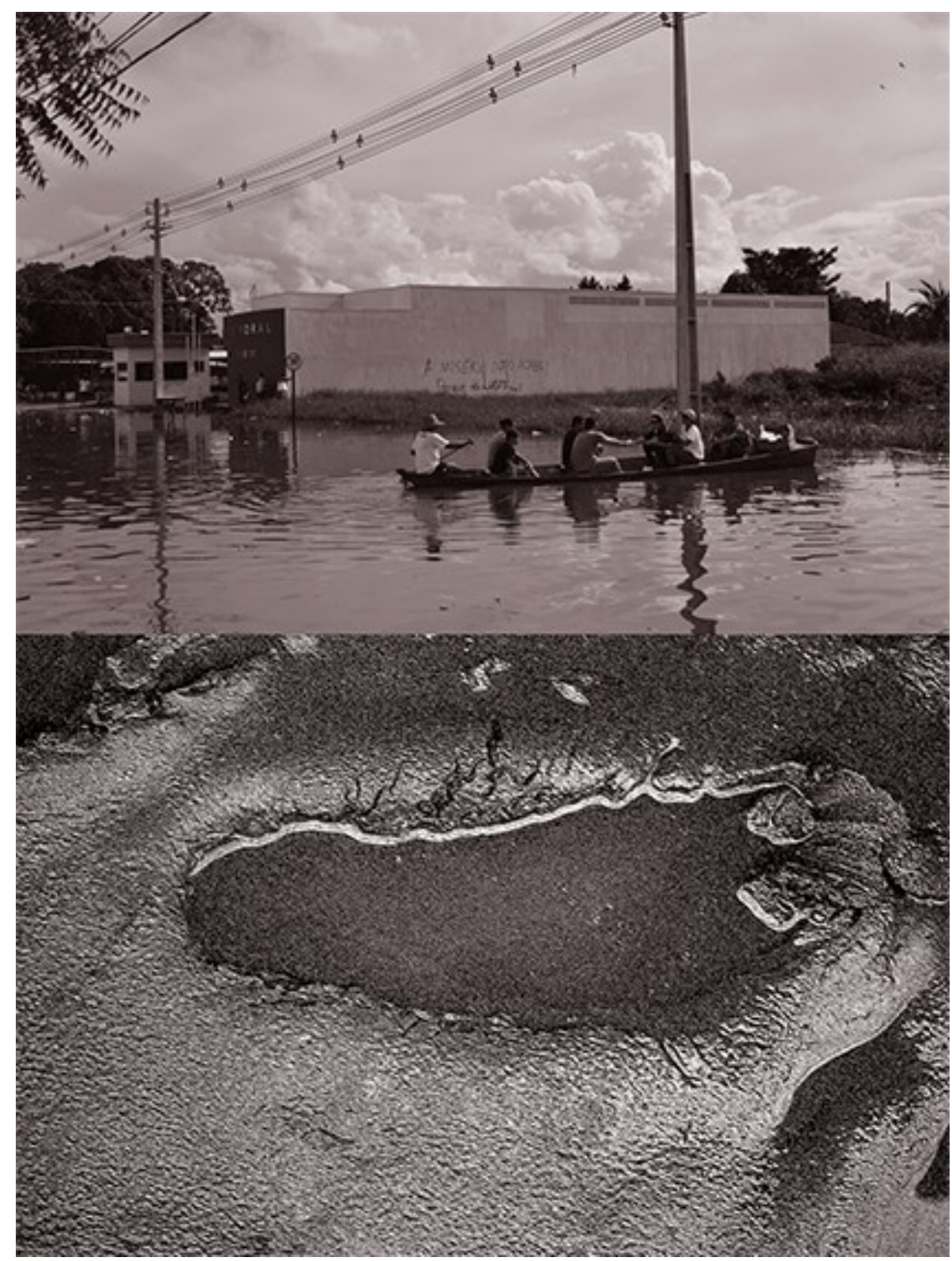




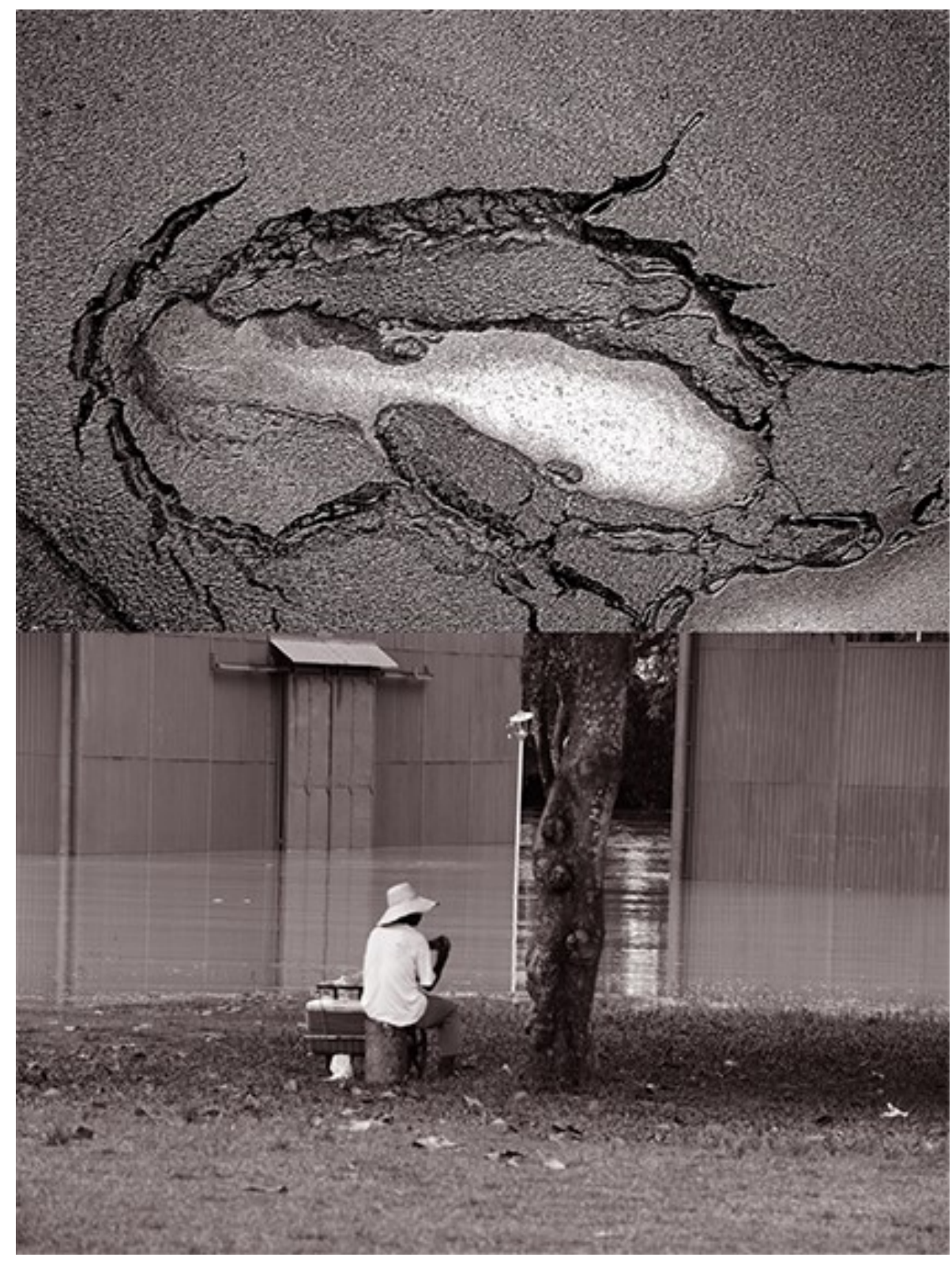




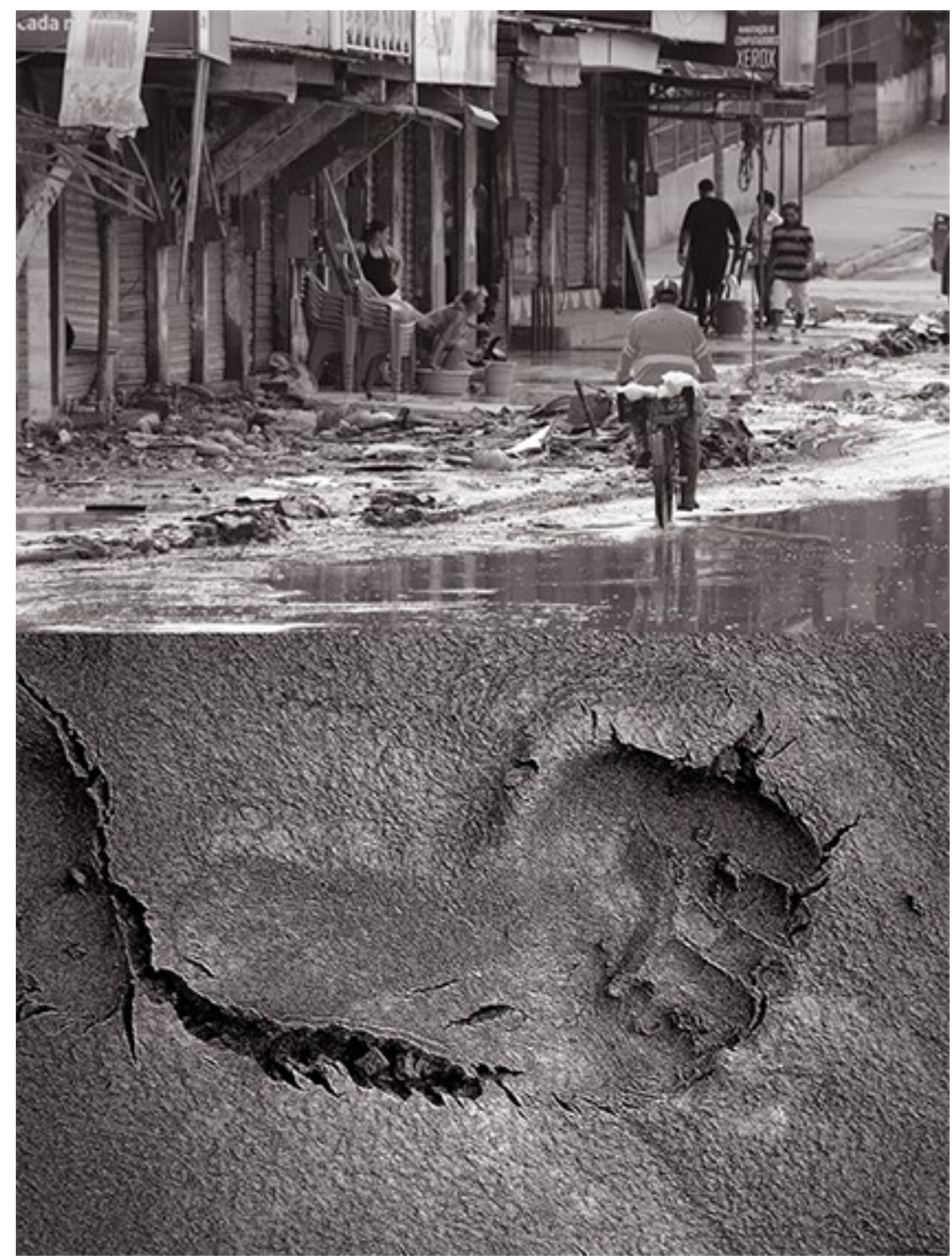




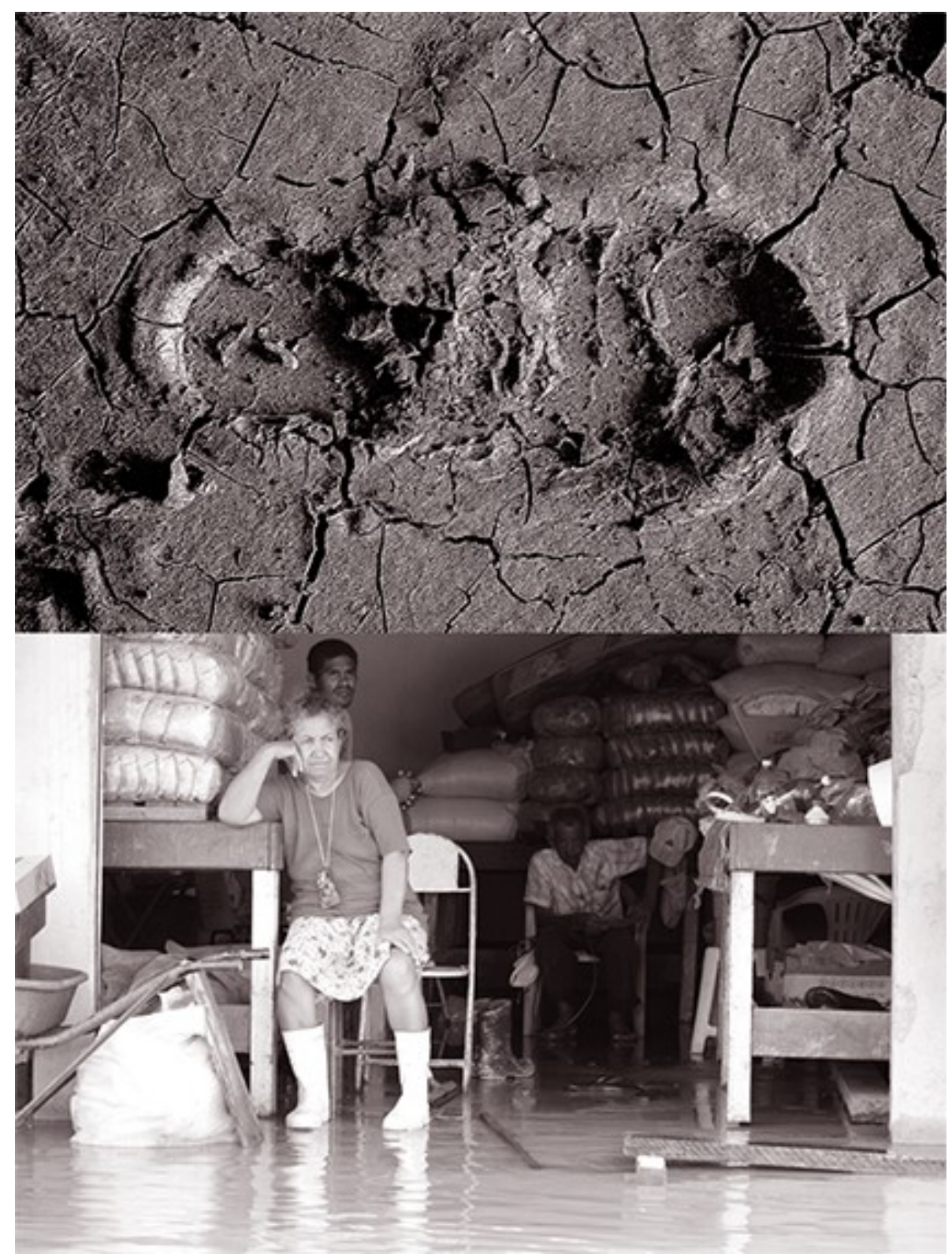

